P-ISSN: 2541-6960; E-ISSN: 2549-8754

Yupa: Historical Studies Journal

Vol. 4 No. 1, 0000 (29-39)

http://jurnal.fkip.unmul.ac.id/index.php/yupa

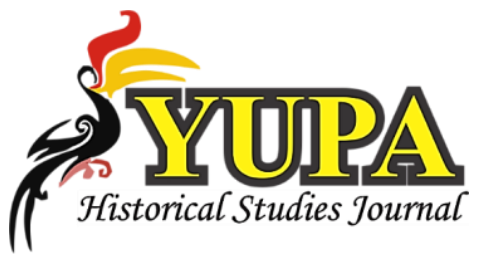

\title{
Developing Digital Book Based on Lafran Pane' Thought for Increasing State Defend Attitude of Students
}

\author{
Umi Azizah' $^{1}$, Djono $^{2}$, Akhmad Arif Musaddad ${ }^{3}$ \\ 1Universitas Sebelas Maret, Surakarta, Indonesia \\ 2Universitas Sebelas Maret, Surakarta, Indonesia \\ 3Universitas Sebelas Maret, Surakarta, Indonesia \\ 1 azizahumia@gmail.com, ${ }^{2}$ djono_sk@yahoo.com, ${ }^{3}$ akhmadarifmusadad@staff.uns.ac.id
}

\begin{tabular}{ccc}
\hline Received & Accepted & Published \\
$14 / 07 / 2020$ & $02 / 09 / 2020$ & $10 / 09 / 2020$ \\
\hline
\end{tabular}

Abstract In the globalization era, technology development grows rapidly. The development of technology accompanied with the decreasing of states defend attitude among Indonesian. This phenomenon evidenced by development of life that has been influenced by foreign culture, of sectarian solidarity, individualism, primordial, and the moral degradation of Indonesian which can threaten the integration of the nation. Education has an important role to deal with these problems. Teachers must be able to find instructional innovations that can be used to improve state defend attitude of students, because very important for future of the nation. Instructional innovation can be used by revive characters which it contains the values of state defend in the form of digital books. Lafran Pane is one of the Indonesian heroes who have thoughts about an intellectual's attitude towards the progress of the nation and state, especially students. Lafran Pane emphasized that student must be able to love their homeland, be hold on their beliefs, reform of thought in all fields, create harmony between religions, and be aware of their obligations as a fighter to elevate national dignity. Lafran Pane's thought contain the values of state defense and moral can be integrated in education. This paper aims to provide learning innovations to improve state defend attitude of students.

Keywords: digital book, Lafran Pane, state defend attitude, attitude of students, Indonesia

\begin{abstract}
Abstrak Di era globalisasi, perkembangan teknologi berkembang pesat. Perkembangan teknologi dibarengi dengan menurunnya sikap bela negara di kalangan masyarakat Indonesia. Fenomena tersebut dibuktikan dengan perkembangan kehidupan yang telah dipengaruhi oleh budaya asing, solidaritas sektarian, individualisme, primordial, dan degradasi moral bangsa Indonesia yang dapat mengancam integrasi bangsa. Pendidikan memiliki peran penting untuk mengatasi masalah tersebut. Guru harus dapat menemukan inovasi pembelajaran yang dapat digunakan untuk meningkatkan sikap bela negara peserta didik, karena sangat penting untuk masa depan bangsa. Inovasi pembelajaran dapat digunakan dengan menghidupkan kembali karakter-karakter yang di dalamnya terkandung nilai-nilai bela negara dalam bentuk buku digital. Lafran Pane merupakan salah satu pahlawan Indonesia yang memiliki pemikiran tentang sikap intelektualnya terhadap kemajuan bangsa dan negara, khususnya pelajar. Lafran Pane menegaskan bahwa mahasiswa harus mampu mencintai tanah air, berpegang teguh pada keyakinannya, mereformasi pemikirannya di segala bidang, menciptakan kerukunan antaragama, dan sadar akan kewajibannya sebagai pejuang untuk mengangkat martabat bangsa. Pemikiran Lafran Pane mengandung nilai-nilai bela negara dan moral yang dapat diintegrasikan dalam pendidikan. Tulisan ini bertujuan untuk memberikan inovasi pembelajaran untuk meningkatkan sikap bela negara siswa.
\end{abstract}

Kata kunci: buku digital, Lafran Pane, sikap bela negara, sikap mahasiswa, Indonesia 


\section{INTRODUCTION}

Every nation and state that has been independent has its own historical journey, either do for Indonesia. Struggle of Indonesian freedom is full of obstacles, until its independence is recognized by the world. The independence that has been achieved by republic heroes, solely only wants to liberate the Indonesian state. Independence is a legacy for the next generation, so they will not feel the difficulty of life under colonized state. The results of the struggle of the nation heroes have brought the Indonesia to the industrial revolution era 4.0. This revolution is shown by the development of technology in various fields (Drath \& Horch, 2014: 51-52).

The Indonesian nation and state are able to survive and keep up with the times, through the process of civilization that produces a modernization. Behind the rapid progress of Indonesia, there are moral degradation and the weakening of the nation's integrity. Moral degradation and the weakening of the nation's integrity that develops among the people of Indonesia is one of the negative impacts of technological development in the globalization era. The development of technology has made it easier for various information from around the world to be accessed by Indonesian, especially for the adolescents.

Indonesian millennial generation lives in the rapidly growing of technology. Based on research in America (Pew Research Center, 2010) states that millennial generations have privatized their social media accounts. If the usage of technology is misused by the adolescents, and various information is received absolutely without the critical thinking. The moral of the young generation will be easily influenced by negative things. They will be easily influenced by foreign cultures that can threaten his identity as an Indonesian.

The threat of national identity caused by foreign influences and moral degradation that occurs among the adolescents can affect the integrity of the nation. As an example, how promiscuity of adolescent's irregularities in morals and norms in Indonesia. The type of food consumed daily has also been influenced by foreign culture, the way of dressing begins to eliminate courtesy norm. Dissemination of hoaxes on government policies has caused public hatred to the state government system. Dispute that occur in the social media can cause disunity among the people of Indonesia. Cybercrime both in the form of hacking, cracking, and spamming of public institution sites carried out by the people who dislike certain parties.

Some of the examples above reflect the phenomena and action that can damage the nation integrity. Weakening of nation integrity reflects the bad attitude of defending the nation. In such conditions, it is very necessary to maintain national unity. The adolescents, especially students, is the main key to improving nation integrity. The students are a group of people who are most aware of the importance of the building their nation and country. Therefore, education has an important role to defend nation integrity with the good attitude of defending the nation state. 
Education in schools is one way to improve the state defense attitude for students. The average age of students in high school is 16 to 18 years. In this age period, adolescents easily to accept various views and influences in their life. Millennial generation usually used gadget, so it is easy for them to get various information from anywhere, both positive and negative information. At this time, their mindset and identity as Indonesians can be easily influenced. Therefore, it is very important to develop state defense attitude against foreign influence.

In the nature of education, classroom learning can be used by teachers to build student's state defense attitude. Teachers can create various learning innovations, one of among the innovations is by reviving the thoughts of hero figures that contain state defense and moral values. One hero whose thoughts contain state defense values and moral values is Lafran Pane. Lafran Pane, one of the figures confirmed as an Indonesian hero by President Joko Widodo on November 6, 2017. His thought about intellectual attitude towards nation and country contains state defense and moral values can be applied to students.

Teaching history having a very important role in improving the attitude state-defense students. As manifested by Kasmadi (1996: 13) that the purpose of teaching history nothing to promote better nationality, love of country and nation. Teachers can use teaching history by developing digital history of teaching materials. To apply thought Lafran Pane and those values are contained therein to students. As we know so far, teaching materials history each very minimal shaped digital and discussed about ideas figures hero in which containing values state defense. This is very important to increase students attitude state defense in this era. Digital books are one of the right choices in the current era, see students preferred to use gadgets as a means of learn from than printed books. This paper was written to provide learning innovations which can enhancing state defense attitude among high school students.

\section{METHOD}

This research was conducted at SMAN Kutowinangun, Kebumen, in Central Java. This study used qualitative methods that are descriptive analysis. The steps are among others (Moleong, 2014: 155-223): data collection writers get from observation, interview, and documentation. After that, writer do validation and the analysis of the data that has been obtained.

\section{RESULT AND DISCUSSION}

\section{Facts in The Field}

Revitalitation the values thoughts of hero figures that contain state defense values and moral values in learning history, to increase attitude state defense students is very important. Based on the results of preliminary studies, attitude of state defense students in SMA N Kutowinangun is at a moderate level. So far students in SMA N Kutowinangun studies figures a 
hero in teaching history is merely only what is in textbook. The purpose of studying history is not only to understand students about past historical events. But also to increase the love of his homeland, increase the spirit of nationality, and increase the attitude of defending students. During this time when students ask about hero figures only limited to browsing on the internet. Of course, it is not effective in the learning process. For that reason, needed media in innovative teaching history, one of them is by developing digital teaching materials.

Digital teaching materials that discuss biographies, thoughts, humanistic heroes. So, the students would be easier studies and not get bored because they did not have to bring a printed book. This was a good step in a strategic and way to increase attitude state defense students through the development of digital book history that discusses about ideas the heros and in it containing moral value and state defense. With the teaching digital history and can be applied to smartphone students will be motivated to read and learn. In this globalization era, smartphone has been a need of for young generation, especially among students. We can create interesting teaching materials, one of which is by using media that is close to students.

\section{Lafran's Profile}

Lafran Pane was born on April 12, 1923 in Kampung Pangurabaan, Sipirok. He is son from Sutan Pangurabaan Pane and his first wife. Lafran Pane is the younger than his six siblings. Lafran Pane's began his education with learning religion about sifat dua puluh and reading the Holy Qur'an. Then Lafran Pane started formal school in the Pesantren Muhammadiyah Sipirok. Later he moved to Sibolga as the capital of the central Tapanuli Regency for continue his education in the HIS (Hollandsch-Inlandsche School) Muhammadiyah. After that, he returned to his homeland and continued his education to Ibididaiyah and finally to Wustha (Sitompul, 2008: 176-178).

Lafran moved to Jakarta in 1937 as the result of his brother Armijn Pane and Sanusi Pane's request. In Jakarta, Lafran continued his education in the seventh grade of HIS Muhammadiyah, then continued the Muhammadiyah MULO class, then Muhammadiyah AMS, then to Jakarta Raya Park. Due to the religious knowledge that he gained during his childhood time, Lafran became a religious figure in his youth. One of the prominent characteristics of Lafran is tenacious and pertinacious in achieving and struggling for his idealism. If Lafran had intended to decide on a goal because God, he would try to achieve that goal (Sitompul, 2008: 178).

Lafran Pane's education continued until the Sekolah Tinggi Islam (STI). During his study, Lafran Pane was active in the activism movement, later he was classified as initiator of Indonesian freedom proclamation. Agus Salim Sitompul (2008: 180) wrote that there were four groups that played an important role in the August 17, 1945 proclamation. First, there were Soekarno and Hatta as golongan tua, second there were youth and student, third there were military group known as PETA, and the last was a mixed along the three group. 
Lafran Pane and his friends belonged to the fourth group who played an important role in the proclamation of August 17, 1945. Lafran Pane was very concerned about the situation of students who were confronted with the elements and the western education system that led to secularism and insulted religion at that time. This is necessary for the development of the newly independent Indonesian nation. Therefore, Lafran Pane initiated establishment of the Himpunan Mahasiswa Islam (HMI) as a forum to foster students to become academically and devoted for people and responsible for realizing a justice and prosperous society and adhering to Islam. Lafran Pane then served his country in education until his death on January 25, 1991.

\section{Lafran Pane Thought Regarding the Attitude of An Intellectual to The Development of Nation And Country.}

Lafran Pane's concern for the condition of students at the time, led him to issue his ideas about an intellectual's attitude towards the development of nation and country. Lafran argued that students who are intellectual groups have a very important role in the progress of the Indonesian nation and state. Satria (2010: 187) in his book entitled "Lafran Pane: Jejak Hayat dan Pemikirannya" wrote Lafran Pane's idea about attitude of an Indonesian intellectual towards nation and country, especially for Muslim intellectuals.

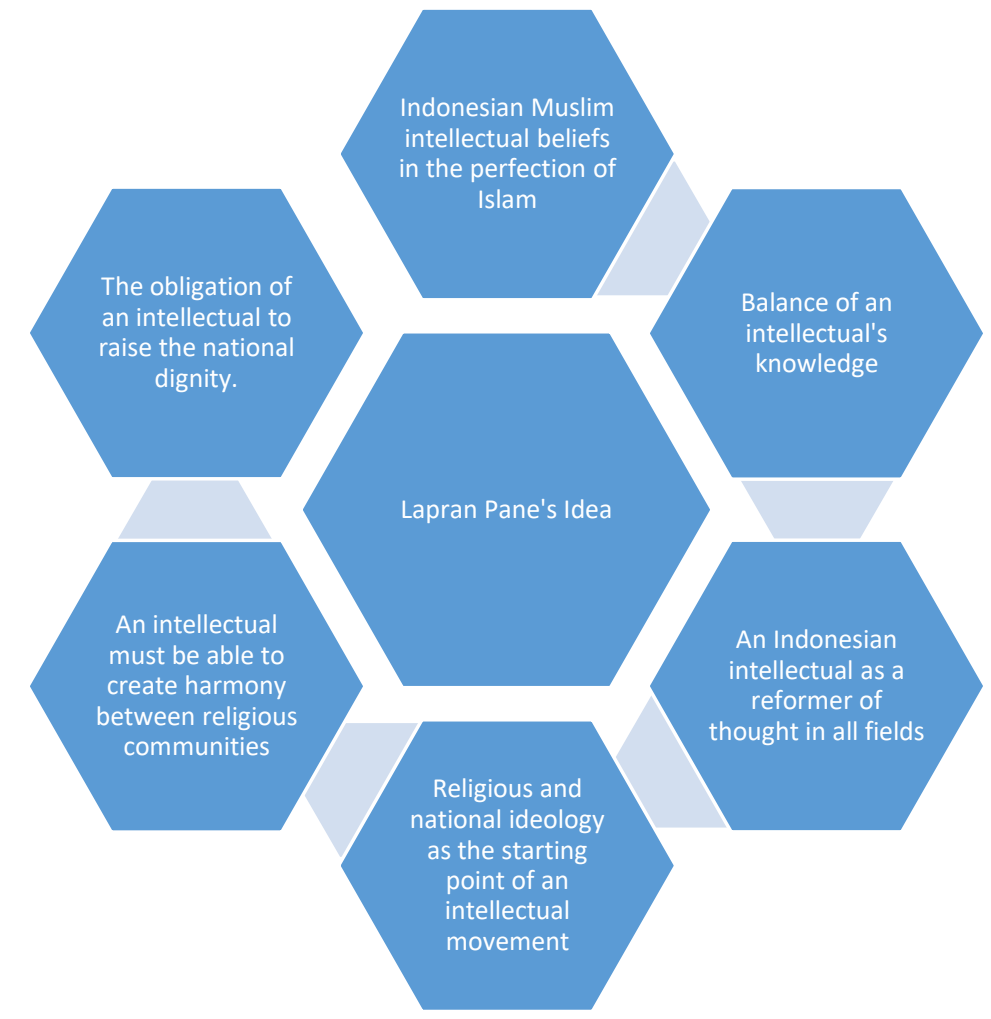

Picture 1. The Ideas of Lafran Pane for Muslim Intellectuals

Firstly, Indonesian Muslim intellectual beliefs in the perfection of Islam. Indonesian people, who are predominantly Muslim, must be able to cling to their beliefs. Lafran Pane stated that, if Islam were practiced by the Indonesian people the invaders (netherland) would not colonize Indonesia for a long time. The invaders understood the weakness of the Islamic 
education among the Indonesian people at that time. Therefore, Lafran tried to be present in the midst of students, to revive the importance of adhering to Islam and not being easily influenced by outsiders.

Secondly, balance of an intellectual's knowledge. It is mean the balance of dunia and akherat duties, the balance between scientific and the faith (iman), as well as the balance between intellectual obligations and beliefs. Students must be able to place knowledge in religious, scientific and moral services. Thus, as students will not be easily influenced by outside influences in all aspects, because the knowledge possessed is supported by tenacious belief. Thus, Indonesia will advance with the efforts of its own people without being affected by matters relating to outside influences.

Students of youth who are vulnerable to get negative influences from outside and can lead to moral decadence. Muthohar (2013: 1) states that this is a difficult problem if only relying on secular western psychological theories. Muthohar stated that Islamic education was able to provide solutions to these problems, namely with functional, integral, and progressive strategies. Muthohar's opinion streng the ned Lafran Pane's thought, that it was very important to provide religious education to students. So that their soul has two abilities, first world knowledge which is able to bring him to adapt with their environement, and religious knowledge that is able to bring him to be firm in his beliefs. So that it will not be easily affected by things that can harm him, his nation and country.

Thirdly, an Indonesian intellectual as a reformer of thought in all fields. As students must be sensitive to developments of their country. The renewal process will never stop, especially when the nation needs the presence of a religion that is able to respond to the latest problems. This renewal of knowledge emphasizes the importance of awareness for students of the role of knowledge in accelerating the development of the nation and state. John L Esposito (2011: 14) states that national thoughts to achieve national goals will foster a spirit of nationality. The renewal of thinking is certainly aimed at the benefit of the nation and the country. Therefore, a student must be able to channel his thoughts toward the interests of the nation.

Fourth, religious and national ideology as the starting point of an intellectual movement. Lafran stated that religious and national is insights no longer need to be contested, considering that most Indonesians are Muslim. Both are not contradictory aspects and complement each other. Lafran Pane advised the young generation, especially students "wherever you stand, always remember Indonesia and Islam". Thus, the unity of the nation will be created, because Islam teaches equality and tolerance. As students must have a tenacious grip on their nation and state.

Fifth, an intellectual must be able to create harmony between religious communities. The Indonesian nation is known as a pluralistic nation, consisting of various tribes, races, and 
languages, as well as different beliefs and religion. This allows the Indonesian people to be vulnerable to confront between groups. A student must be able to create harmony within the religion he adheres to, harmony between religious communities in his environment, and harmony of their nation and state. As example, recently the Indonesian nation faced with inter-group conflict that caused by differences of opinion between each other.

These problems can be overcome by tolerance. Students must be able to respect the opinions of others and use their knowledge to overcome the conflict that often occur in their environment. Elevate democratic attitudes which reflect the values of democracy that applied in Indonesia (Sariyatun et all, 2018: 114). Lafran affirmed that the assessment of other people is not in the level of knowledge and religion, but from the attitude of the person.

Sixth, the obligation of an intellectual to raise the national dignity. In the commitment of intellectual struggle for the sake of the glory of the Indonesian people, Lafran stated "if the determination has not been achieved, whatever challenges must be faced". Students must be able and ready to fight for the advance of their nation and country. In carrying out its obligations as a activist to elevate the dignity of their nation, students can utilize their knowledge to contribute in advancing the nation, creating harmony in the nation and state, raising tolerance and mutual respect among others, and being able to contribute social and national activities.

Lafran was very concerned about Indonesia's post-independence fate. Therefore, students as the people who are aware of Indonesia's further development, have an important role in this case. So, it is very important to make students aware about balance of knowledge and defense of the state is also important. Lafran's figure did not stop at his thinking about the attitude of an intellectual (especially Muslim intellectuals) towards the development of his nation and country, but also as an intellectual who devoted himself to the field of education.

\section{The Values That Contained in Lafran Pane's Thought}

Lafran Pane's thoughts contain the values of morality and defending the country which are include loyality to the country, civic obligation awareness, convinced that the Pancasila is the state ideology, willing to struggle for the nation and the state, and have ability to defend the country (Widodo, 2011: 19). Furthermore it also contains religious, nationalism, responsibility, peaceful love, tolerance, hard work, creative, independent, and democracy values. These values can be built in students, so they have a good personality and aware of their responsibilities in maintaining the identity of the nation and country.

Students must love their homeland so that they do not easily accept the ideology that is brought by invaders. In loving their homeland, students must have tenacious belief as a guide in dealing with their life, especially caused by rapidly changed. If the youth is firm in its life guidelines, Indonesia will not be easily colonized again. Students must be able to socialize well with their society. Respecting others opinion and peaceful love to maintain unity. 
The love of a citizen for his homeland does not just arise. The teacher must be able to build that love in his students. The teacher can introduce the history and circumstances of the country to students. Thus, students will feel proud of their country so it canissue their love to the homeland. According to Gruev in Albena (2011: 35) "Everyone must know both history and geography of his land, he must know it laws and regulation, otherwhise he will not be able to love it well and to serve it well". The Gruev statement can also be imitated by the Indonesian people, that in order to love their homeland they must know the history and circumstances of its country.

Students must be aware of the importance of national and state awareness. Lafran Pane emphasized that a student must be able to create harmony between religions. Indirectly, Lafran ordered students as intellectuals to realize that they live in a multicultural nation. Awareness of nation and state can be demonstrated by participating in maintaining the sovereignty of the nation and country. Awaken the spirit of nationality and end up with high democratic values.

Every nation and state certainly have a state ideology. Indonesian state ideology is Pancasila, and an intellectual must believe that Pancasila is the state ideology. Therefore, unity in the nation and state will be realized. Student must realize that Pancasila is not a science, but a state ideology that must be maintained. According to Yudi Latif (Latif, 2012: 524) that one of the ways to maintain state hegemony can be done by planting state ideology. An intellectual must be able to contribute to maintaining Pancasila as a state ideology. In maintaining the ideology and nation, students are ready and willing to sacrifice for the nation and state.

Willingness to sacrifice for the sake of the nation and the state can be started with active learning, utilizing its knowledge to reform ideas for the sake of development and dignity of the nation and country, and elevate moral values behavior. Armed with his knowledge and determination, intellectual student can be able to demonstrate ability to defend his country. State defense is not only done with participation in military service but can also be done by contributing to the advancement of the nation and country. Like having a good personality, respecting each other's opinions, creating harmony among people, elevating democratic attitudes, obeying existing regulations, loving local products, maintaining local culture, and much more that can be done with good things. An advanced nation and state are not spared from the behavior of its people moral and character.

\section{Implementing Lafran Pane's Thoughts Values in Education with Digital Books}

Lafran Pane's thoughts values are very important to be instilled in the school environment, especially at the high school. According to Smaldino et all (2012: 23), strategies in learning are teaching procedures that have been selected to assist teachers in achieving their education goals. Therefore, the teacher must be able to find various pedagogy innovations that can be used to implement Lafran Pane's thoughts values in classroom learning. At this time, it is 
very necessary to have good attitudes for a student, one of them the values of Lafran Pane's thought.

Thomas Lickona (2015: 7) writes two main goals of education, firstly guiding the young generation to be intelligent and have good behavior. In this case moral education is very important for youth, especially for students. If the morality of the young generation is good then their attitude is also good, because the attitude is determined by the moral they have. If the moral of the intellectuals is good and aware of the importance of the development of their nation and state, their state of defense will automatically grow by itself. The two goals above are very appropriate if they are owned by the younger generation in the current era of globalization, especially for students who are attending high school.

Students in high school enter an age where their psychological maturity has not been fully achieved. They really need guidance in the formation to be a good person. Their lives are easily affected by problems that often occur around them, while they are assets for the advancement of the nation and state. The reality that is being faced by the Indonesian people today is the moral degradation among the youth and the weakening of the nation's integrity. Therefore, it is very necessary to instill moral and state defence values to broaden its views of life. Thus, moral degradation and the weakening of the nation's integrity can be overcome.

In implementing the attitudes and values reflected in Lafran Pane's thoughts, we can use digital books, namely textbooks published in digital form. Develop historical digital books that discuss the thoughts of Lafran Pane and the values contained therein. Digital book into the right choice to revitalize thought Lafran Pane and those values are contained therein to increase attitude state defense students. Fasimpaur stated (in Prasetya, 2015: 65) that students consider digital books to be unique and easy. As a result, students will read more often when they get access to digital books. Plus, under the current circumstances, where gadgets into a essential needs for students and become always brought it wherever they go. With a historical digital book about the thought of Lafran pane, they will often read without having to bring a printed book.

Digital books according to Polanka (in Finita, 2015: 6) can provide various types of interesting learning environments, such as providing demonstrations and interact with animation, does puzzles, repeat question, tried various kinds of responses, gain of a feedback rapid, do alterations learning environment. Digital books, in manufacturing can use additional application to make it more interactive as by adding features interactive quiz, interactive cartoon equipped with audio, video, etc. So, students will be interested and motivated to keep reading material in the digital books.

Making use of things that are close to students to improve the attitude state defense of students is an interest that we must realize in the current era. State defense, nationality and moral values for the younger generation are very important. The phenomenon in Indonesia today that 
this insight among the younger generation is starting to fade. If this phenomenon continues, then the Indonesian nation and state will be divided, making it easier for foreign to infiltrate and recolonize. So at this point it is very necessary to revitalize and actualize the state's defense perspective, nationality, and national moral and cultural values that need to be reintroduced to the youth.

Kochhar (2008: 62-63) states that through history, students can gain knowledge about various actions carried out by the heroes of the nation and state. By reading and studying their lives, students can get inspiration to imitate them. The right learning can prepare the way for the development of the nation and state. Therefore, it is very important for the history teacher to introduce students to the heroes and their thoughts in the life of the nation and state. The teacher must introduce the history of his people more deeply, to increase students love of the nation and country.

The theory behavioristic see learning is the changes behavior as a result of the reaction a stimulus and the response (Budiningsih, 2005: 20). Through historical digital books about the thought of Lafran pane, there will be responses from students after reading and understanding the material in the digital book. Students will understand the importance of the role of young people in defending the country in the current era. They will also realize that defending the country is not always done by taking part in the war, but it can also be done with achievement, adhering to religion, upholding the values of tolerance, loving peace, caring for and maintaining local culture. In the era of technology that is growing rapidly, through history digital books is one of the effective steps to revitalize the values of Lafran Pane's thinking as an innovation in learning to improve students' state defense attitude

\section{CONCLUSION}

The integrity and identity of the nation began to be weakened due to the influence of foreign culture into Indonesia. Unity of the nation are threatened. This is marked with the increasingly globalization era and technology. Easy information to be accessed that can in directly affect the nation's mindset. With such conditions, it is very necessary to defend the Indonesian nation.

Embed the attitude of state defense through the thoughts of hero figures that contain state defense and moral values is the right choice. It will revive their thoughts and introduce them to students. Lafran Pane's thoughts about an intellectual's attitude towards the development of the nation and state contain the values of state defense and morals that can be integrated in each subject.

Broadly speaking, the thought of Lafran Pane contained religious, state defense and moral values. Lafran Pane's thoughts and the values contained therein are very necessary to be instilled 
in every student. Develop historical digital books can be used to implement the Lafran pane thought and the values contained in the history learning in the classroom. By teaching thoughts of the heroes that contain state defense, nationalism, and moral values through education can help overcome the social problems faced by the Indonesian nation and state.

\section{REFERENCES}

Albena, H. (2011). History Education and Civic Education. Journal of Social Science Education. Volume 10. Number 1.

Drath, R. \& H. A. (n.d.). Industrie 4.0: Hit or Hype ? IEEE Indrustrical Electronic Magazine.

Finita, Dewi. (2015). Proyek Buku Digital: Upaya Meningkatkan Keterampilan Abad 21 Calon Guru Sekolah Dasar Melalui Model Pembelajaran Berbasis $\quad$ Proyek. Jurnal Metodik Didaktik. Volume 9. Number 2.

Kasmadi, Hartono. (1996). Model-model dalam Pengajaran Sejarah. Semarang: Ikip Semarang Press.

Kochar, S. (2008). Teaching of History. Jakarta: PT Gramedia Widiasarana Indonesia.

Latif, Y. (2012). Intelegensia Muslim dan Kuasa: Genealogi Intelegensia Muslim Indonesia Abad ke20. Jakarta: Democracy Project.

Lickona, T. (2015). Education For Character. Jakarta. PT Bumi Aksara.

Moleong, L. J. (2014). Metodologi Penelitian Kualitatif. Bandung. PT Remaja Rosdakarya

Muthohar, S. (2013). Antisipasi Degradasi Moral di Era Global. Jurnal Pendidikan Islam, Volume 7. Nomor 2.

Prasetya, D. D. (2015). Kesiapan Pembelajaran Berbasis Buku Digital. Jurnal Teknologi Elektro dan Kejuruan. Volume 24. Number 2.

Pew Research Center. (n.d.). Millennials A Portrait of Generation Next: Confident, Connected, Open to Change. Retrieved from Www.pewresearch.org/millennials. Diakses pada 30 Agustus 2018.

Sariyatun, Joebagio, H., \& Sumardjoko, B. (2018). Proliferation of democratic education in Indonesia: The influence measurement of tolerance, multiculturalism, and historical awareness on the democratic attitude. New Educational Review. Volume 52.

Satria, H. W. (2010). Lafran Pane: Jejak Hayat dan Pemikirannya. Jakarta Selatan: Penerbit Lingkar.

Sitompul, A. (2008). Sejarah Perjuangan Himpunan Mahasiswa Islam 1947-1975. Jakarta. CV Misaka Galiza.

Smaldino, S. E. (2012). Instructional Technology and Media for Learning. Jakarta: Kencana.

Widodo, S. (2011). Implementasi Bela Negara Untuk Mewujudkan Nasionalisme. Jurnal Ilmiah CIVIS. Volume 1. Number 1. 